\title{
Online learning during COVID-19 pandemic: a cross sectional survey of students' perception
}

\author{
Vemuri V. Rani* \\ Department of Pharmacology, Terna Medical College, Navi Mumbai, Maharashtra, India
}

Received: 21 August 2021

Accepted: 13 September 2021

*Correspondence:

Dr. Vemuri V. Rani,

Email: veenaranivemuri@gmail.com

Copyright: $\odot$ the author(s), publisher and licensee Medip Academy. This is an open-access article distributed under the terms of the Creative Commons Attribution Non-Commercial License, which permits unrestricted non-commercial use, distribution, and reproduction in any medium, provided the original work is properly cited.

\begin{abstract}
Background: The corona virus pandemic had an impact on the student's education especially the medical and dental students. There was no option but to continue the education by using the online platforms to take lectures. This survey aims at finding out the students' perception towards these online classes.

Methods: After ethics committee approval, a pre-validated questionnaire was administered as a Google form to the first, second bachelor of medicine and bachelor of surgery (MBBS) students and first, second bachelor of dental surgery (BDS) students, data was analyzed using descriptive statistics in Microsoft excel.

Results: Out of 400 students who were sent the questionnaire 169 answered, with a response rate of $42.25 \% .43$ (25.44\%) students had responded that the availability of the PowerPoint presentation for future reference makes it better for their study. 59 (34.91\%) students said the main problem with the online lectures was Internet connectivity and technical issues /buffering during the class. Mean was 3 and above for three questions regarding the interaction during online classes and missing face to face interaction with both faculty and students.

Conclusions: There is a positive attitude towards online learning, but the students miss the face-to-face interaction with the faculty and students. There is a necessity for improving the required infrastructure as well as training the faculty for the use of online platforms for planning and undertaking the sessions in an interactive way keeping in view the future occurrence of similar situations.
\end{abstract}

Keywords: Cross sectional study, Online learning, Undergraduates, E-learning, Survey

\section{INTRODUCTION}

E-learning or distance learning was there since the improvement in technology happened with the development of worldwide web. The introduction of a variety of electronic gadgets (i.e. smart phones, tablets and computers etc.) has facilitated us to provide education outside of a classroom. Teachers who are well versed with use of technology are vital for the success of e-learning. The new technologies make the teachers to undertake new duties as well as innovate newer methods of teaching. ${ }^{1}$ Electronic (e) or online learning can be defined as the use of electronic technology and media to deliver, support and enhance both learning and teaching and involves communication between learners and teachers utilising online content. However, there are significant costs involved in designing and implementing an online module. This is an initial cost and later it decreases. ${ }^{2}$ E-learning is as effective and with many advantages compared to traditional learning Although e-learning was always there it became more important at the time of corona virus pandemic. $^{3}$

The corona virus disease (COVID-19), had an impact on Indian education, economy and population on a large scale. This had brought life to a standstill. The students were no exception to this. In fact, they were affected more since most of them were going through the exam phase or the preparation for an upcoming exam phase. Keeping in view the spread of the virus and its impact on the public 
health infrastructure, leading to a significant mortality rate the government had proposed a complete lockdown of all places. The guidelines issued by the government mandated that schools and colleges be kept shut for a prolonged period of time to prevent the spread of the virus. The medical and dental colleges therefore were closed since as compared to a normal classroom these colleges have a larger intake of students. Most of the students who lived in remote parts of India went to their homes. The coronavirus pandemic has seen the introduction of different methods of delivering education to medical students all over the world. Lectures have rapidly been developed to be delivered online as webinars using various platforms such as Zoom. Universities started adopting an open-book examination approach. ${ }^{4}$ A virtual classroom and electronic media came to the rescue of both the faculty and students in India as well. A virtual classroom with online classes can be done in the safe environment of our house anywhere in India. It helped us to continue medical education.

Most of the medical colleges started using the platforms like Zoom, Microsoft Teams and Google meet for conduct of online lectures. The department of pharmacology, Terna Medical College started using these modes of delivery for online lectures, distribution of study material and assignments to the students. Creation of a Google classroom helped in distribution of the required material and assignments as well as conducting exams. Students could access all of these at their current location.

Even though online learning or e-learning was known to us for quite some time, the corona pandemic had given the first opportunity for the students to experience the remote mode of learning exclusively. The students of medical and dental colleges are usually not exposed to this kind of teaching as till now the curriculum had only didactic lectures and practicals.

But where it was good that an online class can be attended safely, students need the interaction with faculty and peers for an overall development. Not all students are capable of concentrating on the material being provided online.

There are advantages and disadvantages in distance education. Some of the advantages are self-paced study, time and space flexibility, time saving in terms of travel and the fact that a distance learning costs less. Disadvantages include a sense of isolation, the struggle with staying motivated, lack of face-to-face interaction, difficulty in getting immediate feedback, the need for constant and reliable access to technology. ${ }^{5}$ Though this was said about a distance education course, it holds true even for the present situation. Online learning need more understanding of how students perceive and react to elements of e-learning by both the developers and teachers. ${ }^{6}$

There is also a requirement of basic electronic items like a phone, tablet, laptop, or a desktop, as well as good internet connectivity. In India, not all places will have good network access and therefore some of the students may not be able to use this mode of education. Thus having a better understanding of the advantages and disadvantages of online lecture delivery can help incorporation of this into regular curriculum reducing the travel time for students and also help them to access the material and lectures at their own pace. Most of the studies done so far were on the distance education provided by universities in comparison to the face to face traditional teaching methods. ${ }^{7}$ However, these were done in universities where the curriculum contained online learning in some form or the other in their curriculum. In countries like India medical curriculum is mostly based on traditional teaching methods and was suddenly transitioning into the online lectures due to the pandemic.

Therefore, little research was conducted that addresses perceptions of students on online courses in medical curriculum. The present study was hence planned to assess the medical and dental students' perception of online learning when compared to face to face learning.

\section{Objectives}

Objectives were to assess the perception of medical and dental students on learning using distance education/online learning techniques in comparison to regular classroom teaching.

\section{METHODS}

After taking the requisite permissions from the institutional ethics committee, a cross-sectional study was conducted. A study questionnaire was developed after a literature search on the different online modes of lecture delivery used, advantages and disadvantages, also after discussion with students and faculty on the difficulties associated with it. The study questionnaire contained a total of 20 questions as a Google form. The questions were divided into - the demographic data like age, class, and college; the device used to attend the classes and the internet connectivity; there were 5 questions on the students' perception on faculty's approach to the course material, and their confidence after attending the online classes, these were on a 5 point Likert scale with 5 being excellent, 4 above average, 3 average, 2 below average and 1 very poor; 6 questions were regarding the interactivity and availability of the faculty for clarifications and the amount of time spent on online lectures and assignments, these were added to gauge the students' perspective on requirement of physical interaction; and there were 5 free text feedback questions on the students' likes and dislikes regarding the online classes and how they can be improved.

A total 400 students belonging to the first, second MBBS and first, second year BDS students of Terna Medical College and Terna Dental College, Navi Mumbai were sent the study questionnaire as a Google form. The participation was voluntary and the informed consent was 
made as part of the form and that the participants were nonidentifiable and the data will be used for research purposes only.

The study was conducted during November- December of 2020. As it was a single point contsct programme there is no study duration.

\section{Statistical analysis}

Data was entered in Microsoft excel. The demographic data and data regarding the instrument used for attending online classes was analysed using descriptive statistics as percentages. Percentages, mean and SD were calculated for the perception questions in Likert scale separately for both dental and medical colleges. Data regarding the number of hours spent attending the online lectures and number of hours spent online for assignments was analysed using descriptive statistics. The open ended questions and suggestions were analysed after clubbing the data of both medical and dental colleges together.

\section{RESULTS}

There were 169 responses from the students. Table 1 shows the age distribution of the students of dental and medical colleges. There were 20 students from BDS first year and 59 students of BDS second year, 32 students from MBBS first year and 57 students from MBBS second year.

Most of the students, $87.3 \%(n=69)$ of Terna Dental College and $85.56 \%(n=77)$ of Terna Medical College, were using a smart phone to attend the online lectures.

Of the 79 students of Terna Dental College, 67 (84.81\%) students said they were spending 2-4 hours for online classes per day, whereas $33(37.08 \%)$ students were spending the same time from Terna Medical College. 54 $(60.67 \%)$ students from the Terna Medical College had said they spent 1-2 hours on online classes. A total 44 (55.7\%) students from Terna Dental College reported to have been spending 1-2 hours on activities related to class, whereas $37(41.57 \%)$ students of Terna Medical College said they were spending 1-2 hours on activities related to class.

Table 1: The age distribution of the student population shown as $n(\%)$.

\begin{tabular}{|lll|}
\hline $\begin{array}{l}\text { Age in } \\
\text { years }\end{array}$ & $\begin{array}{l}\text { Terna Dental } \\
\text { College } \mathbf{N}(\%)\end{array}$ & $\begin{array}{l}\text { Terna Medical } \\
\text { College } \mathbf{N}(\%)\end{array}$ \\
\hline $\mathbf{1 8}$ & $7(8.9)$ & $2(2.2)$ \\
\hline $\mathbf{1 9}$ & $32(40.5)$ & $29(32.2)$ \\
\hline $\mathbf{2 0}$ & $27(34.2)$ & $25(27.8)$ \\
\hline $\mathbf{2 1}$ & $10(12.7)$ & $23(25.6)$ \\
\hline $\mathbf{2 2}$ & $3(3.8)$ & $7(7.8)$ \\
\hline $\mathbf{2 3}$ & 0 & $4(4.4)$ \\
\hline Total & $79(100)$ & $90(100)$ \\
\hline
\end{tabular}

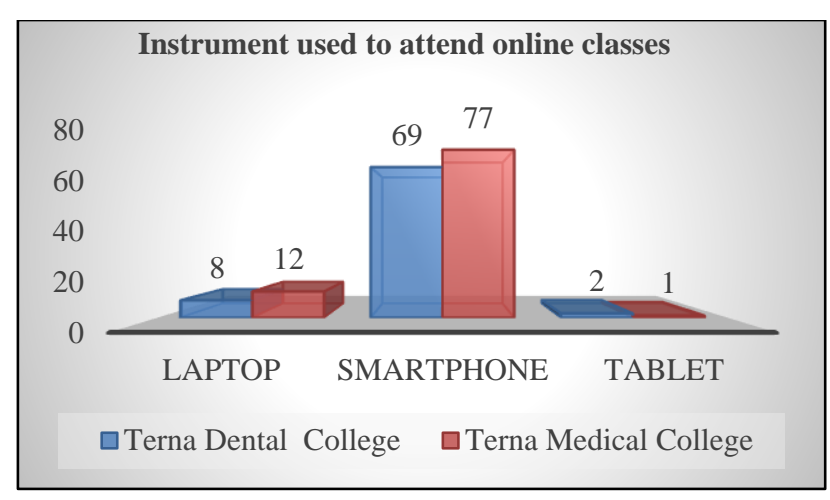

Figure 1: Distribution of data regarding instrument used to attend online classes.

The maximum number of students from Terna Medical College $(n=76)$ and Terna Dental College $(n=57)$ reported to have problems with Internet connectivity sometimes during their online lectures.

Table 2 shows the data regarding perception of students to online classes and the mean was 3 and above for three questions regarding the interaction during online classes and missing face to face interaction with both faculty and students.

The open ended questions data from both medical and dental college were analysed together. In the questions where they were required to write in their own words what they liked and disliked about the online lectures, 43 $(25.44 \%)$ students had responded that the availability of the power point presentation for future reference makes it better for their study. They felt that this was reducing the time taken to make notes. $17(10.06 \%)$ students loved the fact that they can attend the lectures in the comfort of their house. $48(28.4 \%)$ students liked the fact that they don't have to travel and this was saving a lot of time. Most of them felt that the faculty were more available for interaction during an online lecture, and doubts could be cleared more with individual attention. The disturbances which most of the students face during a normal lecture were not there here as the students were muted, this helped them to concentrate more on the lecture.

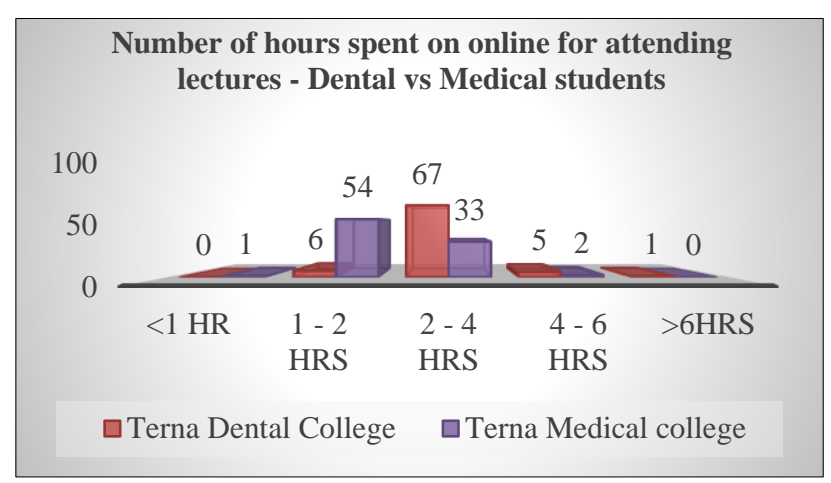

Figure 2: Number of hours spent by the students attending online lectures during the COVID-19 pandemic. 


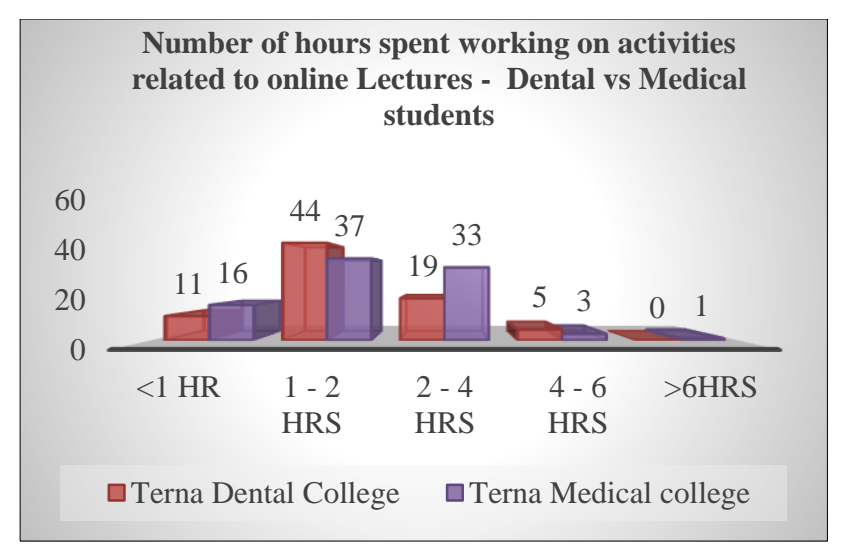

Figure 3: Number of hours spent working on activities related to the online topics covered.

$59(34.91 \%)$ students said the main problem with the online lectures was Internet connectivity and technical issues /buffering during the class. 55 (32.5\%) students said that there was less interaction with teachers and students during an online class as compared to only $16(9.47 \%)$ students saying that there was interaction with faculty. 32 (18.93\%) students said that they miss face to face interaction with other students and the faculty, the class room environment. This also reflected in Table 2.

A few said that staring at the screen for prolonged period was causing strain to their eyes. Since the teacher cannot see what they are doing the class is not taken seriously. They said they were missing the practical knowledge gained through dissections and demonstrations.

In suggestions on how these classes can further be improved, most of them wanted the lectures to be taken on a single platform. They wanted faculty to share the notes and power point presentation of lectures. As most of them had left to their homes without taking their practical journals and textbooks they needed this material for studies. They felt that summarizing the topic at the end of lecture and discussion of the important questions would be helpful.

Overall the major problem according to them was internet connectivity and otherwise they felt that it was a new, enjoyable and great experience.

Table 2: Students perceptions on online teaching on 5-point Likert scale with 5 being excellent and 1 being very poor. Likert scores are shown as both percentages and mean and SD.

\begin{tabular}{|c|c|c|c|c|c|c|c|c|}
\hline Question & College & Excellent & $\begin{array}{l}\text { Above } \\
\text { average }\end{array}$ & Average & $\begin{array}{l}\text { Below } \\
\text { average }\end{array}$ & $\begin{array}{l}\text { Very } \\
\text { poor }\end{array}$ & Mean & SD \\
\hline \multirow{2}{*}{$\begin{array}{l}\text { Understanding } \\
\text { of the topic } \\
\text { taken during } \\
\text { online classes }\end{array}$} & $\begin{array}{l}\text { Terna Dental } \\
\text { College }\end{array}$ & $7.6(6)$ & $26.6(21)$ & $50.6(40)$ & $7.6(6)$ & $7.6(6)$ & 2.78 & 0.93486 \\
\hline & $\begin{array}{l}\text { Terna Medical } \\
\text { College }\end{array}$ & $10(9)$ & $31.1(28)$ & $43.3(39)$ & $12.2(11)$ & $3.3(3)$ & 2.6854 & 0.93657 \\
\hline \multirow{2}{*}{$\begin{array}{l}\text { Amount of } \\
\text { subject material } \\
\text { covered in online } \\
\text { classes }\end{array}$} & $\begin{array}{l}\text { Terna Dental } \\
\text { College }\end{array}$ & $12.7(10)$ & $38(30)$ & 36.7 (29) & $8.9(7)$ & $3.8(3)$ & 2.5 & 0.92231 \\
\hline & $\begin{array}{l}\text { Terna Medical } \\
\text { College }\end{array}$ & $14.4(13)$ & $38.9(35)$ & $31.1(28)$ & $13.3(12)$ & $2.2(2)$ & 2.5056 & 0.97844 \\
\hline \multirow{2}{*}{$\begin{array}{l}\text { How logically } \\
\text { and clearly the } \\
\text { content was } \\
\text { delivered }\end{array}$} & $\begin{array}{l}\text { Terna Dental } \\
\text { College }\end{array}$ & $12.7(10)$ & $34.2(27)$ & $41.8(33)$ & $7.6(12)$ & $3.8(3)$ & 2.5513 & 0.94865 \\
\hline & $\begin{array}{l}\text { Terna Medical } \\
\text { College }\end{array}$ & $13.3(12)$ & $30(27)$ & $38.9(35)$ & $13.3(12)$ & $4.4(4)$ & 2.6629 & 1.02185 \\
\hline \multirow{2}{*}{$\begin{array}{l}\text { Availability of } \\
\text { the faculty } \\
\text { during online } \\
\text { classes for } \\
\text { discussion or } \\
\text { clarifications }\end{array}$} & $\begin{array}{l}\text { Terna Dental } \\
\text { College }\end{array}$ & $43(34)$ & $29.1(23)$ & $20.3(16)$ & $3.8(3)$ & $3.8(3)$ & 1.9615 & 1.0744 \\
\hline & $\begin{array}{l}\text { Terna Medical } \\
\text { College }\end{array}$ & 38.9 (34) & $26.7(25)$ & $20(18)$ & $8.9(8)$ & $5.6(5)$ & 2.1461 & 1.2018 \\
\hline \multirow{2}{*}{$\begin{array}{l}\text { Confidence } \\
\text { about knowledge } \\
\text { on the subject }\end{array}$} & $\begin{array}{l}\text { Terna Dental } \\
\text { College }\end{array}$ & $7.6(6)$ & 17.7 (14) & $50.6(40)$ & $16.5(13)$ & $7.6(6)$ & 2.9615 & 0.95947 \\
\hline & $\begin{array}{l}\text { Terna Medical } \\
\text { College }\end{array}$ & $4.4(4)$ & $27.8(25)$ & $45.6(41)$ & $15.6(14)$ & $6.7(6)$ & 2.9213 & 0.94418 \\
\hline \multirow{2}{*}{$\begin{array}{l}\text { Enjoyment of the } \\
\text { online classes }\end{array}$} & $\begin{array}{l}\text { Terna Dental } \\
\text { College }\end{array}$ & $10.1(8)$ & $27.8(22)$ & $\begin{array}{l}39.29 \\
(31)\end{array}$ & $10.1(8)$ & $\begin{array}{l}12.7 \\
(10)\end{array}$ & 2.8462 & 1.11748 \\
\hline & $\begin{array}{l}\text { Terna Medical } \\
\text { College }\end{array}$ & $13.3(12)$ & 21.1 (19) & $38.9(35)$ & $15.6(14)$ & $\begin{array}{l}11.1 \\
(10)\end{array}$ & 2.9101 & 1.16424 \\
\hline \multirow{2}{*}{$\begin{array}{l}\text { Opportunities } \\
\text { for interaction } \\
\text { during online } \\
\text { classes }\end{array}$} & $\begin{array}{l}\text { Terna Dental } \\
\text { College }\end{array}$ & $3.8(3)$ & $5.06(4)$ & $\begin{array}{l}36.71 \\
(29)\end{array}$ & $\begin{array}{l}34.18 \\
(27)\end{array}$ & $\begin{array}{l}20.25 \\
(16)\end{array}$ & 3.641 & 0.97999 \\
\hline & $\begin{array}{l}\text { Terna Medical } \\
\text { College }\end{array}$ & $2.22(2)$ & $\begin{array}{l}11.11 \\
(10)\end{array}$ & $\begin{array}{l}28.89 \\
(26)\end{array}$ & $\begin{array}{l}31.11 \\
(28)\end{array}$ & $\begin{array}{l}26.67 \\
(24)\end{array}$ & 3.6742 & 1.05287 \\
\hline
\end{tabular}




\begin{tabular}{|c|c|c|c|c|c|c|c|c|}
\hline Question & College & Excellent & $\begin{array}{l}\text { Above } \\
\text { average }\end{array}$ & Average & $\begin{array}{l}\text { Below } \\
\text { average }\end{array}$ & $\begin{array}{l}\text { Very } \\
\text { poor }\end{array}$ & Mean & SD \\
\hline \multirow{2}{*}{$\begin{array}{l}\text { Missed direct, } \\
\text { in-person } \\
\text { interaction with } \\
\text { other students }\end{array}$} & $\begin{array}{l}\text { Terna Dental } \\
\text { College }\end{array}$ & $2.53(2)$ & $6.33(5)$ & $\begin{array}{l}24.05 \\
(19)\end{array}$ & $\begin{array}{l}18.99 \\
(15)\end{array}$ & $\begin{array}{l}48.1 \\
(38)\end{array}$ & 4.0256 & 1.10459 \\
\hline & $\begin{array}{l}\text { Terna Medical } \\
\text { College }\end{array}$ & $2.22(2)$ & 3.33 (3) & $\begin{array}{l}16.67 \\
(15)\end{array}$ & $\begin{array}{l}32.22 \\
(29)\end{array}$ & $\begin{array}{l}45.56 \\
(41)\end{array}$ & 4.1685 & 0.96808 \\
\hline \multirow{2}{*}{$\begin{array}{l}\text { Missed direct, } \\
\text { face to face } \\
\text { interaction with } \\
\text { the faculty }\end{array}$} & $\begin{array}{l}\text { Terna Dental } \\
\text { College }\end{array}$ & $1.27(1)$ & $8.86(7)$ & $\begin{array}{l}25.32 \\
(20)\end{array}$ & $\begin{array}{l}22.79 \\
(18)\end{array}$ & $\begin{array}{l}41.77 \\
(33)\end{array}$ & 3.9359 & 1.07316 \\
\hline & $\begin{array}{l}\text { Terna Medical } \\
\text { College }\end{array}$ & $4.44(4)$ & $6.67(6)$ & $\begin{array}{l}26.67 \\
(24)\end{array}$ & $\begin{array}{l}27.78 \\
(25)\end{array}$ & $\begin{array}{l}34.44 \\
(31)\end{array}$ & 3.8427 & 1.08606 \\
\hline
\end{tabular}

\begin{tabular}{|c|c|c|}
\hline $\begin{array}{c}\text { Frequency distribution of what the students liked most about learning through online platforms( } \\
\text { Both Medical and dental college data together) }\end{array}$ \\
30 \\
30 \\
10
\end{tabular}

Figure 4: Responses to an open ended question regarding what the students liked most about learning through online platforms. The most common responses were selected and plotted in the graph.

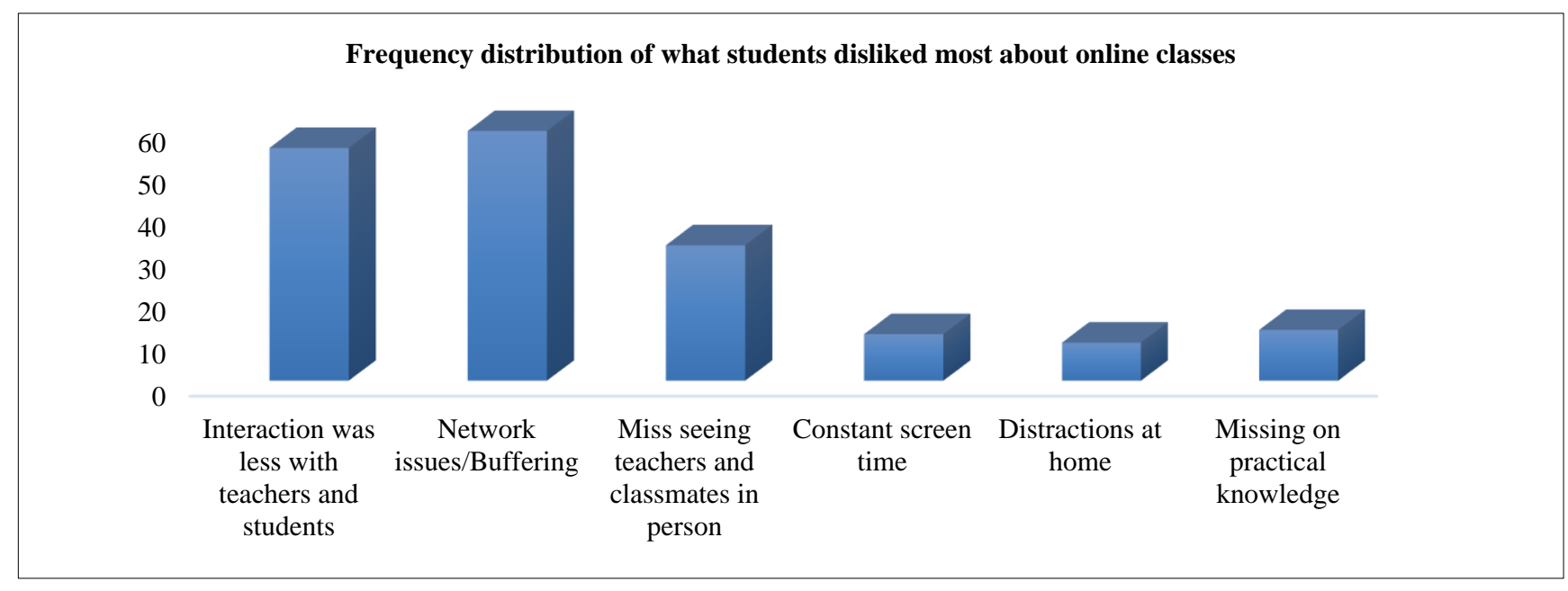

Figure 5: Responses to an open ended question regarding what the students disliked most about learning through online platforms. The most common responses were selected and plotted in the graph.

\section{DISCUSSION}

The survey was conducted to learn the students' perceptions to distance learning techniques in comparison to face to face learning. Till the time of COVID-19 this method was never used for teaching undergraduate students and therefore was new to both the faculty as well as the students. Hence there was some time taken for adjustment to the virtual learning techniques.
In a survey conducted by Moazami et al in Iran the students had shown a positive response towards virtual learning in comparison to face to face learning. ${ }^{8}$ But they had actually designed, implemented and evaluated a virtual learning method. We had plunged into it as it was necessary during the pandemic. Remote access to lectures was important in COVID-19 pandemic and in our survey it was seen that this was one of the advantages the students felt regarding online lectures. Our study had a moderate outcome to virtual learning. The students missed the interaction with colleagues and teachers that comes with attending college. 
E learning helps students to quickly access the study material when and where they want. ${ }^{9}$ This reflected in our survey as well. The availability of power point presentation for reference was one of the advantages of Elearning according to our students. Our survey had shown that students were happy with the online delivery of lectures with regards to saving time taken to travel to and from the institute. This was in accordance with the previous survey that was done on undergraduate students in Portugal, United Arab Emirates (UAE) and Ukraine by Fidalgo et al that said that the advantage of online learning was that it was self-paced and time saving. ${ }^{10}$ In our survey the online learning during the pandemic were synchronous sessions and as far as possible the time table of the preCOVID time was maintained. There was no self-paced learning as they were not recorded lectures and were more a session conducted in video conferencing platform. Keeping the future in mind it may be better to conduct at least a few sessions this way and further there is a necessity to plan and then conduct a session. There is a requirement to increase the online assignments a student can submit as this helps student in revising the subject as well as is time saving for the faculty as the answers can be keyed in before administering the test. A virtual session may not work when it comes to clinical subjects as the practical interaction with patients is necessary, unless we can have advanced technology in our institutes that can help students with a virtual patient as was done by Mcgee et al itself at the Harvard Medical School-Beth Israel Deaconess Mount Auburn Institute for Education and Research. ${ }^{11}$ Studies which were conducted previously about the cost effectiveness of the E-learning had shown that it can help reduce travel costs, labour costs and institutional infrastructure. ${ }^{12}$ Although these were done in non-medical colleges, the cost associated with setting up the required infrastructure is only for a single time and then the cost decreases. This holds true for any institute. A study conducted by Golchai et al at Guilan University of Medical Sciences there was comparison between e learning and traditional teaching methods. They devised a virtual medical teaching package and found that the students who used this scored better in histology. ${ }^{13}$

The distance learning or E-learning or virtual education is not without its disadvantages. These include a sense of isolation, the struggle with staying motivated, lack of faceto-face interaction, and difficulty in getting immediate feedback, the need for constant and reliable access to technology. These need to be addressed before we can make virtual learning as a part of curriculum. There is also a necessity to be ready for any future episodes of this kind especially academically by keeping in place both synchronous and asynchronous methods of teaching in medical schools to prevent a break in education. This can be done by developing learning modules, recorded lectures and structured assignments which can be done at students' pace and also incorporate a video conferencing lecture series so that the contact with teacher is also available. As was done by Jiang et al, they had provided twelve tips for conducting online classes during the pandemic, they had observed that because of inadequate preparation of the Universities for this kind of teaching they were facing challenges. ${ }^{14}$ This is true for Indian setting where we were totally unprepared for a complete online teaching. There is a necessity to incorporate this method in the curriculum, update the necessary infrastructure for the same and train teachers in the use of this mode of delivery of content. There is a need for medical educators to gain an understanding of online platforms and technologies and to understand that their own teaching methods have to shift to accommodate the online environment. ${ }^{15}$

The drawbacks of our study were that the response rate was less and we could have also included the third year MBBS and BDS students in the survey. That would have given a comparison between clinical and paraclinical teaching.

\section{CONCLUSION}

Our survey was aimed to find the perceptions of medical and dental students regarding the online lectures being conducted during the COVID-19 pandemic. We found that the response was moderate one. The students liked that it was saving time and can be attended in the safe environment of the house, but they missed interacting with faculty and students in college environment. There is a need for incorporating the online method of teaching into regular curriculum and also to train the faculty for the same keeping in view the future. There is a requirement of upgrading the infrastructure in the medical colleges as well for this purpose.

\section{ACKNOWLEDGEMENTS}

Authors would like to thank all the medical and dental undergraduate students for taking the time to fill out the form and submit it. The author acknowledges the immense help received from the scholars whose articles are cited and included in references of this manuscript.

Funding: No funding sources

Conflict of interest: None declared

Ethical approval: The study was approved by the Institutional Ethics Committee

\section{REFERENCES}

1. Hoq MZ. E-Learning During the Period of Pandemic (COVID-19) in the Kingdom of Saudi Arabia: An Empirical Study. Am J Educ Res. 2020;8(7):457-64.

2. Howlett D, Vincent T, Gainsborough N, Fairclough J, Taylor N, Cohen J, Vincent R. Integration of a CaseBased Online Module into an Undergraduate Curriculum: What is Involved and is it Effective? ELearning and Digital Media. 2009;6(4):372-84.

3. George PP, Papachristou N, Belisario JM, Wang W, Wark PA, Cotic Z, et al. Online eLearning for undergraduates in health professions: A systematic review of the impact on knowledge, skills, attitudes and satisfaction. J Glob Health. 2014;4(1):010406. 
4. Sandhu P, de Wolf M. The impact of COVID-19 on the undergraduate medical curriculum. Med Educ Online. 2020;25(1):1764740.

5. Smart KL, Cappel JJ. Students' Perceptions of Online Learning: A Comparative Study. J Inform Tech Educ Res. 2006;5:201-19.

6. Dost S, Hossain A, Shehab M, Abdelwahed A, AlNusair L. Perceptions of medical students towards online teaching during the COVID-19 pandemic: a national cross-sectional survey of 2721 UK medical students. BMJ Open. 2020;10:e042378.

7. Ananga P, Biney IK. Comparing Face-to-Face and Online teaching and learning in higher education. MIER J Educ Stud Trends Pract. 2017;7(2):165-79.

8. Moazami F, Bahrampour E, Azar MR, Jahedi F, Moattari M. Comparing two methods of education (virtual versus traditional) on learning of Iranian dental students: a post-test only design study. BMC Med Educ. 2014;14:45.

9. Zehry K, Halder N, Theodosiou L. E-Learning in medical education in the United Kingdom. Procedia Social and Behav Sci. 2011;15:3163-7.

10. Fidalgo P, Thormann J, Kulyk, O. Students' perceptions on distance education: A multinational study. Int J Educ Technol High Educ. 2020;17:18.
11. McGee JB, Neill J, Goldman L, Casey E. Using multimedia virtual patients to enhance the clinical curriculum for medical students. Stud Health Technol Inform. 1998;52(2):732-5.

12. Baczek M, Zaganczyk-Baczek M, Szpringer M, Jaroszynski A, Wozakowska-Kapłon B. Students' perception of online learning during the COVID-19 pandemic: a survey study of Polish medical students. Medicine. 2021;100(7):e24821.

13. Golchai B, Nazari N, Hassani F, Bahadori MH. Computer-based E-teaching (Virtual Medical Teaching) or Traditional Teaching: A Comparison Between Medical and Dentistry Students. Procedia Social and Behav Sci. 2012;47:2080-3.

14. Jiang Z, Wu H, Cheng H, Wang W, Xie A, Fitzgerald SR. Twelve tips for teaching medical students online under COVID-19. Med Educ Online. 2021;26:(1):1854066.

15. O'Doherty D, Dromey M, Lougheed J. Barriers and solutions to online learning in medical education - an integrative review. BMC Med Educ. 2018;18:130.

Cite this article as: Rani VV. Online learning during COVID-19 pandemic - a cross sectional survey of students' perception. Int J Basic Clin Pharmacol 2021;10:1202-8. 